\title{
The Effect of Sporting Habits and Different Variables on Self-Esteem of Police Officers
}

Erdoğan Tozoglu*

Gökhan Bayraktar*

M. Ertuğrul Ozturk*

Serkan T. Aka*

\begin{abstract}
Having low or high self-esteem is considered to have an effect on one's attitude to wards himself or her self as well as to wards other individuals in the society. The refore, it is importantto determine the factors that improve individuals' self-esteem. Considering that the quality of education obtained by an individual has an impact on selfesteem, it is imperative to pointout what factors in the education process boostone's self-esteem and to execute such factors. The purpose of this study is to investigate the effect of sporting activities on selfesteem of police officers with respect to different variables. The total of 266 police officers, 32 female and 234 male, who serve in the City of Erzurum in Turkey participated in this survey. Scale of Self Esteem, developed by Kuzgun (2005), was used in order to gather data. T test and variance analysis were utilized as well. The difference among the groups' choices is evaluated based on P 0.05 significancelevel. Based on the evaluation of the survey results, no difference among police officers was observed in terms of average self-esteem with respect to gender and sporting habits, where as, a difference was observed in terms of average self-esteem with respect to the type of sport performed. Those who perform individual sportst end to have higher self-esteem compared to those who perform team sports or no sport at all. Since, having police officers with high self-esteem serve and interact with individuals will have a positive effect on social interactions in the society. It is imperative to provide opportunities and encoruge policeofficers to do individual sports and to further study the factors that may help increase the self-esteem of such individuals.
\end{abstract}

Keywords: Self-esteem, Individuality, Sporting and Police Officers

\footnotetext{
* Corresponding author: Erdoğan TOZOĞLU, Assist. Prof. Atatürk University, Agri Ibrahim Cecen University, Turkey; email: etozoglu@ hotmail.com

* Corresponding author: Gökhan Bayraktar, Assist. Prof. Atatürk University, Agri Ibrahim Cecen University, Turkey; e-mail: etozoglu@hotmail.com

${ }^{*}$ Corresponding author: M. Ertuğrul Ozturk, Assist. Prof. Atatürk University, Agri Ibrahim Cecen University, Turkey; e-mail: etozoglu@hotmail.com

" Corresponding author: Serkan T. Aka; Assist. Prof. Atatürk University, Agri Ibrahim Cecen University, Turkey; e-mail: etozoglu@hotmail.com
} 


\section{Introduction}

Self-esteem is closely related to one's perception of himself/herself. Human beings with self-recognition and self-awareness realize his/her potentials and begin acting with self-esteem. If an individual trusts himself/herself, realizes his/her strengths and weaknesses and sees himself/herself worthy at his/her current condition, then that person is considered to have self-respect. Self-esteem and self-respect cause a person to respect and value himself/herself. A person who develops selfrespect can get by on his/her own and he/she will be confident in tackling problems he/she is facing. Having a sense of wort hand confidence forms the basis of self-respect and people with such quality tend to become a respected member of the soceity. On the otherhand, people who lacks sense of worth or capability stop enjoying life and start feeling down and incompetent, and they eventually develop a negative attitude towards them selve sand people around them.

It is imperative to clarify two concepts that are usually mis understood: the soceity's perception of a person based on experiences forms selfesteem where as how a person subconciously sees him self/herself determines self-respect, that is, self-respect is a result of an internal selfevaluation. Self-respect results in one's respect towards himself/herself as well as towards his environment and life in general. Self-esteem can not be considered in the absence of self-respect.

It's a commonsense that sport has positive effects on individuals and communities. It manifasts itself on an individual's character as loving, enjoying, seeking his/her rights, being fair, complying with the rules of competition, accepting both failure and success, socializing, making new friends etc (Doğan 2004). Sicil acceptance brings self-esteem. With in peace and self-esteem, one develop esself-respect. Sporting habits result in not only physical endurance and confidence but also spiritual selfawareness and self-discipline, hence self-respect and courage. According to Rosenberg, Baldwin and Hoffman, self-esteem is definedas " the evaluation of the personality positively or negatively'. Self esteem is not a static but a dynamic formation (Rosenberg, 1965 Baldwin and Hoffman, 2002).

While self-respect is influenced by many factors, it also has effect on many phycological mechanisms. For in stance, the level of self-respect one has causes that individual to have beter social relations, more 
academic success (Varl1 1999. Tarhan 1995), higher level of comprehension, less like hood of depression (Skinner 1995, 1996), and happier life (Deiner 1995, 2000. Yorulmaz ve Eryılmaz 2006). Maslow claims that a person must have a healthy level ofself-respect in order to be productive and successful. According to Maslow, self-esteem has two resources: one is the acceptance and appriciation of the love dones, and the other is the sense of competance and accomplishment. (Joseph, 1995).

Police is an armed group in the law enforcement services who maintain public order and safety; it enforces the law equally and fairly, and ful fills the tasks assigned by the law (Yasar Y. 1996). In the most general sense, police is the person who is responsible for the safety of the citizens and their personal possesions, supporting and maintaining the civil life, public order and social welfare. An ideal police officier should be in a healthy physical as well as pycological state. Consistent exercise and sporting habits are essential parts of maintaining such strong and resilient profile (Zorba, 1999). A for mentioned arguments reveal the significance of sporting habits in terms of their positive effects on individuals' phycological, spiritual and physical condition.

\section{Data and Method of Analysis}

The purpose of this work is to study the effect of various factors on police officers' level of self-esteem. Self-esteem scale (SES) was developed by Kuzgun (2005). Self-esteem scale, a Likert type scale, is prepared as 5 grades comprising 20 items. Among the items, 15 of the them were positive 1 yar ranged and 5 of them were negative 1 yar ranged- 3.4.6.7, and 12. There sponses given to the items were graded as "Always', 'Often ', 'Occasionally", ''Rarely" and 'Never'. While "Always" is represented by 5 and "Never" is represented by 1 in positive items, "Always" is represented by 1 and "Never" is represented by 5 in negative items. Low score obtained from the scale corresponds to a lower self-esteem and high score corresponds to high self-esteem.

Internal consistency of the self-esteem scale was calculated based on Cronbech Alpha coefficient, which was 0.81. This shows that scale has a considerably high internal consistency (Kuzgun and Bacanl1,2005). The sample set of there search included 266 police officers, 32 female and 234 male, serving in different departments of the Erzurum Police Department. 


\section{Results}

Analysis results and the related conclusions are presented in this section. Demographic data is given in Table 1, and the frequency distribution of individual in relation to sporting habits is listed in Table 2 . In the study, $t$ test was employed in order to compare the values obtained from SES with respect to gender and marital status; statistical data are reported in Table 3 and 4. Analysis of Variance (ANOVA) was performed to compare the values obtained from SES with respect to sporting habits and the types of sport, the results are shown inTable 5 and 6.

Table 1: Demographical Quality Distribution of Samples

\begin{tabular}{|c|c|c|c|}
\hline & & $\begin{array}{c}\text { Number } \\
(\mathbf{N})\end{array}$ & Percentage \\
\hline \multirow{3}{*}{ Gender } & Female & 32 & 12.00 \\
\hline & Male & 234 & 88.00 \\
\hline & Total & 266 & 100.0 \\
\hline \multirow{4}{*}{ Age } & 24 and less & 76 & 28.60 \\
\hline & Between 25 and 30 & 158 & 59.40 \\
\hline & Between 31 and 36 & 32 & 12.00 \\
\hline & Total & 266 & 100.0 \\
\hline \multirow{3}{*}{ Marital Status } & Single & 120 & 45.10 \\
\hline & Married & 146 & 54.90 \\
\hline & Total & 266 & 100.0 \\
\hline \multirow{4}{*}{ Family Structure } & Elementary Family & 248 & 93.20 \\
\hline & Extended Family & 14 & 5.30 \\
\hline & Decay Family & 4 & 1.50 \\
\hline & Total & 266 & 100.0 \\
\hline \multirow{4}{*}{ Duty Term in the Office } & 2 years and less & 54 & 20.30 \\
\hline & Between 3 and 5 years & 192 & 72.20 \\
\hline & 6 years and more & 20 & 7.50 \\
\hline & Total & 266 & 100.0 \\
\hline
\end{tabular}

Table 2.Status of the Individuals in relation to sporting habits

\begin{tabular}{|c|c|c|c|}
\hline & & $\begin{array}{c}\text { Number } \\
(\mathbf{N})\end{array}$ & Percentage \\
\hline \multirow{4}{*}{ Do you do sport? } & I do not do & 52 & 19.50 \\
\hline & I sometimes do & 186 & 69.90 \\
\hline & I do regularly & 28 & 10.50 \\
\hline & Total & 266 & 100.0 \\
\hline \multirow{4}{*}{$\begin{array}{l}\text { What kind of sport do you } \\
\text { do? }\end{array}$} & Individual Sport & 82 & 30.80 \\
\hline & Team Sport & 132 & 49.60 \\
\hline & I don't do sport & 52 & 19.50 \\
\hline & Total & 266 & 100.0 \\
\hline
\end{tabular}




\begin{tabular}{llccc}
\hline & Yes & & 74 & 27.80 \\
Should it be compulsory to do & No & & 84 & 31.60 \\
sport for work? & Partially & 108 & 40.60 \\
& & Total & 266 & 100.0 \\
\hline \multirow{3}{*}{$\begin{array}{l}\text { Does your job keep you from } \\
\text { sporting? }\end{array}$} & Yes & 30 & 11.30 \\
& No & 166 & 62.40 \\
& Partly & & 70 & 26.30 \\
& & Total & 266 & 100.0 \\
\hline
\end{tabular}

Table 3.Averages Female and Male Police Officers Obtained from Self-Esteem Test and $t$ Values of the Variationsbetween Standard Deviations and Averages

\begin{tabular}{lccccc}
\hline Gender & $\mathbf{N}$ & $\mathbf{X}$ & $\mathbf{S s}$ & $\mathbf{t}$ & $\mathbf{p}$ \\
\hline Female & 32 & 70.87 & 7.24 & 1.59 & \\
Male & 234 & 68.80 & 6.83 & 1.52 & 0.112 \\
& & & & & \\
\hline
\end{tabular}

As shown inTable 3, there is no significiant difference in p:0.05 level between averages of female and male police officers' scores obtained in Self Esteem Scale.

Table 4.t Values, Averages and Standard Deviations for the Female and Male Police Officers' Self-Esteem Test Scores

\begin{tabular}{|c|c|c|c|c|c|c|}
\hline Marital Status & & $\mathbf{N}$ & $\mathbf{X}$ & Ss & $\mathbf{F}$ & $\mathbf{P}$ \\
\hline Single & & 120 & 69.43 & 6.56 & 0.815 & \\
\hline Married & & 146 & 68.73 & 7.18 & 0.822 & 0.412 \\
\hline & Total & 266 & 138.16 & 6.90 & & \\
\hline
\end{tabular}

Data presented inTable 4 showsthatthere is no significant difference in p:0.05 level between the averages of married and single police officers' scores obtained in Self Esteem Scale.

Table 5.Averages and Standard-Deviations for sporting habits and Self-Esteem Test

\begin{tabular}{|c|c|c|c|c|c|c|}
\hline Sporting Case & & $\mathbf{N}$ & $\mathbf{X}$ & Ss & $\mathbf{F}$ & $\mathbf{P}$ \\
\hline I do not do & & 52 & 68.50 & 6.53 & & \\
\hline I sometimes do & & 186 & 68.95 & 7.09 & 0.995 & 0.371 \\
\hline \multirow[t]{2}{*}{ I do regularly } & & 28 & 70.71 & 6.22 & & \\
\hline & Total & 266 & 69.05 & 6.90 & & \\
\hline
\end{tabular}

No significiant difference in p:0.05 level between police officer's sporting habits is observed in terms of averages.

Table 6.Averages and Standard-Deviations of Self-Esteem Test Scores for the Police Officers with individual sport, team sport and no sporting habits 


\begin{tabular}{|c|c|c|c|c|c|c|}
\hline Kind of Sport & & $\mathbf{N}$ & $\mathbf{X}$ & Ss & $\mathbf{F}$ & $\mathbf{P}$ \\
\hline Individual Sport & & 82 & 70.73 & 0.76 & & \\
\hline Team Sport & & 132 & 68.22 & 0.60 & 3.603 & 0.029 \\
\hline I do not do sport & & 52 & 68.50 & 0.90 & & \\
\hline & Total & 266 & 69.05 & 0.42 & & \\
\hline
\end{tabular}

In Table 6, a considerable difference is observed in p:0.05 in terms of self-estee maverages of police officers with respect to individual sport, team sport and no sporting habits $(\mathrm{F}=3,603 ; \mathrm{p}>0,029)$. Based on the selfesteem averages given in Table 6 , among police officers, those who do individual sports $(X=70.73)$ seem to have higher average than those who do teamsport $(X=68.22)$ and those who don't do any sport at all $(X$ $=68.50$ ).

\section{Discussion and Conclusion}

In the study, the relationship between police sporting and sporting habits was examined. As a result of analyses made, it has been found that there is nosignificiant differences statistically between genders and self esteem averages considering the point averages female and male police officers, involved in the study, obtained from the self esteem scale and t values of the differences between Standard deviations and averages. But considering the values, while female police officers self esteem score was $(x=70,87)$, male police officers' self esteem score was $(x=68,80)$. According to these results, it could be said that female police officers' self esteem was higher than that of male police officers. Erman (2004) found that female self esteem rate was higher than that of males in his study, but there was no considerable diffrence statistically.

Considering averages of points married and single police officers obtained from the self esteem scale and $t$ values of differences between Standard deviations and averages, it has been demonstrated that there is no significiant differences marital status and self esteem averages. It was found that married $(x=69,43)$ and single $(x=68,73)$ were on close rates. With regard to sporting activities of police officers, averages of points they obtained and their standard deviations, it was suggested that there was no considerable difference between the self esteem averages of those doing sport $(x=68,50)$, doing sport sometimes $(x=68,95)$, and not doing sport $(\mathrm{x}=70,71)$.

The comment that doing sport doesn't have an effect on self esteem has come to light. Gould (1995) found no important relationship between 
involving in sporting activities and self esteem in a study he carried out on high school students (Aşç1, 1999). In the findings obtained in the study, not finding a difference between sporting and self esteem is parallel with the other studies made in this field. Considering the point averages police officers, doing individual sport, doing team sport and not doing sport, obtained from self esteem scale and Standard deviations, it has been demonstrated that there is a considerable variation between kind of sport and self esteem averages. With regard to self esteem point averages, while self esteem score of police doing individual sport was $(x=70,73)$, the score of police officer doing team sport was $(x=68,22)$ and that of police officers not doing sport was $(x=68,50)$. According to these results, self esteem scores of police officer dealing with individual sport was higher than scores of those who don't do sport. Erşan found that self respect of students doing team sport was lower than that of students doing individual sport in a study he carried out on physical education and sport department students (Erşan 2009). The difference observed between kind of sport and self esteem in this study is in accordance with the other studies made in this field.

As a proposition, it's important to provide required attention and opportunities to attend sporting activiies in order to increase self esteem of police officers as the self esteem has a satisfying effect on individuals' attitudes towards himself/herself and people. By making similiar researches, the impotance of positive influence of determining the effective factors on increasing individuals' self esteem and high self esteem in social relationships should be studied.

\section{References}

Aşç1, F. H. 1999. Self Concept and Sport. Sport Psychology Course. Bayar, P. (Complier). Ankara: Bağırğan Publisher.

Baldwin, S. A. \& Hoffmann J. P. 2002. "The Dynamics of Self-esteem: A Growthcurve Analysis." Journal of Youth and Adolescence. 31 (2), 101-113.

Deiner, E. and Deiner, M. 1995. "Cross-cultural Correlates of Life Satisfaction and Selfesteem." Journal of Personality and Social Psychology, 68, 653-663.

Diener, E. 2000. "Subjective Well-being: The Science of Happiness, and a Proposal for a National Index." American. Psychologist. 55, 3443. 
Dogan, O. 2004. Sport Psychology Course Book. Sivas. Cumhuriyet University Publication. 1: 97.

Erman K. A, Şahan A and Can, S. 2004. "Comparison of Self Respect Levels of Male and Female Sporters." 8th Internetional Sport Science Congress. Antalya.

Erşan, E. E, Doğan O. and Doğan S. 2009). "Self Esteem Level in Physical Education and Coaching Department and Relationship with Some Socio-demographical Qualities." Clinical Psychiatry12.35-42.

Joseph, J. M. 1994. The Resilient Child. New York: Plenum.

Kuzgun, Y. 2000. Vocational Counseling. Nobel Publications and Distributions. Ankara.

Kuzgun, Y. ve Bacanl1, F. 2005. Scales Used in Psychological Counseling and Guidance. Nobel Publication, Ankara, s.149.

Rosenberg, M. 1965. Society and the Adolescent Self-image. Princeton, NJ: Princeton University Press.

Skinner, E. A. 1995. Perceived Control, Motivation, \& Coping. London: Sage Publications.

Skinner, E. A. 1996. "A Guide to Consructs of Control." Journal of Personality and Social Pscyhology, 71, 549-570.

Tarhan, S. 1995. The Effects of Satisfaction Level of High School Students with Their Body Images on Their Self Esteem and Academical Success. Unpublished master's Thesis. HacettepeUniversity. Ankara.

Varl1, O. 1999. Examining the Self Concept Level of 4th Grade Students in Private and State Schools. Unpublished Master's Thesis, Hacettepe University. Ankara.

Yasar, Y. 1996. Police Vocational Law. Ankara. s.152-156.

Yorulmaz, A. \& Eryllmaz, A. 2006. Examining the Relationship Between Adolescent Being Well, Self Esteem and Optimistic Tencency. International 14th. Psychology Congress, Hacettepe University. Ankara. Türkiye.

Yörükoglu, A. 2000. Adolescence. Özgür Publications. İstanbul.

Weinberg, R. S, Gould D. 1995. Fondations of Sport and Exercise Psychology. Human Kinectics. GATA. Ankara.

Zorba, E. 1999. Sport and Physical Fitness for Everybody. Ankara. 